\title{
The Unfamiliar Past: The Outreach of Palaeolithic Archaeology in Greek Archaeological Museums
}

\section{Paraskevi Elefanti}

Department of History and Archaeology, National and Kapodistrian, University of Athens

\begin{abstract}
The way in which the Stone Age was presented in regional museums in Greece was strongly conditioned by the example set by the National Museum in Athens, with its emphasis on the Classical period after independence from Ottoman rule in 1830. Archaeology and museums provided the ideal tools with which to articulate the links between the emerging nation and perceived past glories. Evidence from earlier periods, being less striking and abundant and more difficult to interpret was side-lined, a pattern which persists today in the relatively small number of museums that devote space to the Palaeolithic and Mesolithic. But this is changing and from the early 2000s onwards in both newly built museums and those that were redeveloped, displays focusing on early prehistory have increased in number. This paper looks at ten such museums and how they present the Palaeolithic and Mesolithic. Despite the increase, the numbers are still too few and the quality of the displays is quite variable, to the extent that the ability of most to engage the public imagination is doubtful.
\end{abstract}

Keywords: Greece, Palaeolithic, Museums, Public archaeology, Cultural diversity

\section{Introduction}

Ever since the introduction of the concept of public archaeology by McGimsey in 1972, in which he appealed for the preservation of archaeological heritage for the sake of the "public right to knowledge" (McGimsey 1972:5), the term has gained widespread recognition as an established field within the discipline (Matsuda 2004:67). Public archaeology is now concerned with any area of archaeological activity that interacts with or has the potential to interact with the general public, the vast majority of whom, for a variety of reasons, know little about it as an academic discipline (Schadla-Hall 1999:147). In contrast to traditional archaeology as the study of the past through material culture, public archaeology seeks to enhance the relationship between archaeology and contemporary society (Matsuda 2004). This it does by improving the points of contact 
between archaeologists and the wider world, not only for scientific reasons but also as a means to enrich lives and to stimulate thought, emotions and creativity (Merriman 2004). On the other hand, although it is socially and ethically responsible for archaeology to carry out research focused on questions that resonate with local communities, it is also possible that the answers to these might be uncomfortable for those communities or their members (Hodder 2002).

Although in practice, public archaeology is as old as the discipline itself, as a field of study it is relatively modern, focusing on aspects as diverse as education, national politics and propaganda, to the ethics of repatriating cultural property (Sakellariadi 2011). Public archaeology inspires and mobilises a whole range of people and institutions who are involved not only in the scientific discovery, processing and promotion of cultural history and knowledge, but also in their ideological and symbolic exploitation (Galanidou 2020). Archaeological sites and excavations, as representative loci where research regarding the past is carried out and knowledge created, have often been used as an interface between specialists and the public, not only for communicating archaeological knowledge (Kasvikis et al. 2002, 2007), but also for enhancing communal interaction, creativity and expression through events and performances with references to past and modern life (Hamilakis \& Theou 2013). Museums are amongst the most significant and powerful vehicles for the preservation and reconstruction of the past and for enhancing public engagement in archaeology. However, as their displays cannot speak for themselves, they rely on those who are involved in their promotion to create narratives based on the current ideological approaches and aesthetics. From this perspective, museums are institutions that contribute to the construction of collective memories by choosing which parts of the past will be kept and which will be remain forgotten (Chourmouziadi 2006: 14, and references therein). The development of national museums began during the mid-eighteen century and gradually progressed as part of the national awareness of the middle classes, who claimed for themselves a new political, economic and social role. Prior to this, personal collections made up of heirlooms, precious objects and memorabilia were mostly held by the aristocracy (Chourmouziadi 2006: 29-30).

The nineteenth century was a period during which national movements emerged in Europe as nations strove for their right to independence, for which they sought supporting evidence. In Greece, this was provided by archaeology, which by that time had already become established as an institutionalised discipline (Karamanolakis \& KourtesiPhilippakis 2017). It was used to legitimise the existence and rights of nations as independent states by adding supportive evidence for a national historical narrative and identity (Kotsakis 1991; Diaz-Andreu 1995: 54; Kasvikis et al. 2011, and references therein), implying a cohesive (Sakellariadi 2008: 130) and timeless existence (Plantzos 2017). Museums were one of the main mechanisms of the Greek state for assimilation, incorporation and national manipulation of history (Damaskos \& Plantzos 2008; Hamilakis 2012), a practice which has been repeatedly discussed in terms of the need now to embrace more widely cultural diversity and alternative readings of the past (Kasvikis et al. 2012; Hamilakis 2011).

This discussion has highlighted the need for museums to move towards a more inclusive approach in their depiction of the past, by incorporating a greater variety of social, gender and age groups (Kokkinidou \& Nikolaidou 2000; Hitchcock \& Nikolaidou 2013), a 
conceptual and analytical approach which is not new, having already been argued for in the 1990s (Gero \& Conkey 1991). In addition, museums must provide equal access to all, regardless of their social, educational or financial status. It is also important that museums step-up to the challenges presented by difficult and controversial topics (Gazi 2004; Mouliou 2008), such as immigration, the history and rights of minorities and wartime atrocities. Because many of these events are more recent and are still within the collective memory, they often have the potential to result in misunderstandings.

With these issues in mind, this paper discussed how the Palaeolithic and Mesolithic are presented in Greek archaeological museums. It begins with a brief chronological overview of the social and scientific conditions that prevailed in industrialised Western Europe during the 19th and early 20th centuries, as well as in Greece during the same period. A series of ten museums in which there are sufficient displays of material and information about early prehistory are then presented, with particular emphasis placed on when they were installed and how the evidence is articulated. Also presented will be the small number of early prehistoric caves which have recently been developed, or are in the process of redevelopment, including Theopetra, Franchthi and Petralona.

Through these examples, the paper provides an overview of the present state of museological practices in Greece regarding early prehistory and human origins. It argues that the reasons behind the minimal representation are multifaceted. They include the close link between the implementation of the classical past and how the national narrative was constructed, resulting in limited public awareness and a general perception of little or no cultural progress. Together with the sparse distribution of Palaeolithic evidence, as well as the inaccessibility of many caves and rock shelters, these limit the perceived potential of the Palaeolithic and Mesolithic as a resource worth promoting in terms of attracting visitors and regional development. It needs to be emphasised that in the overview of museums the aim is not to be critical but to provide observations of what is a dynamic process and one which will undoubtedly improve with time. Museums are all under space and financial constraints and many will be chronologically and regionally specific and the fact that they do not cover early prehistory is therefore not surprising.

\section{The birth of Palaeolithic archaeology in Western Europe and Greece}

Palaeolithic archaeology emerged as a component of prehistory in Western Europe during the 19th century, mainly in the United Kingdom and France, which, at the time were centres of political, economic, and cultural development. At the same time, rapid industrialisation caused widespread and fundamental changes to the social and economic fabric of these societies (Trigger 1989:101-102). Large-scale public works unearthed cultural remains and extinct animal species, prompting a re-evaluation of the antiquity of human civilisations when set against traditional biblical accounts. They also imposed the need for the creation of a new chronological and cultural stratigraphic sequence, within which these discoveries would make more sense (Gamble 1986, 2021).

The term Palaeolithic archaeology was coined by the English banker and naturalist Lord John Lubbock, but it was the work initially of the French magistrate Edouard Lartet, and then of the geologist and palaeontologist, Gabriel de Mortillet, who by using palaeontological criteria and archaeological observations respectively, subdivided the 
Palaeolithic period into the phases used today (Trigger 1989: 91-95). Published in 1847, the work of the French archaeologist Jacques Boucher de Perthes on the stratigraphic coexistence of Lower Palaeolithic bifaces and bones of extinct large mammals attributed to an 'antediluvian age', was also significant. Although initially dismissed by both French and English scholars alike, approximately ten years later in 1859, following the investigations of the English scholars Joseph Prestwich and John Evans, the first stratigraphically secure biface was found in-situ within an 'antediluvian' deposit at St Acheul Amiens in France, exactly where de Perthes had focused his research (Gamble \& Kruszynski 2009; Gamble 2021; Trigger 1989: 92).

Following the publication of The Principles of Geology by Charles Lyell in the early 1830s, along with On the Origin of Species in 1859 by Charles Darwin, the three disciplines of Palaeolithic archaeology, geology and palaeontology, began promoting ideas of evolution in nature and society from simpler to more complex forms. All three enjoyed great prestige as they revealed the hitherto unexpected antiquity of humanity and their gradual evolution from very 'primitive' beginnings, which also influenced how early humans were depicted (Moser 1998). These ideas were borrowed by the middle class which had come to view itself as a major force in world history (Trigger 1989:73-93). Palaeolithic archaeology, therefore, came to serve the ideologies of progress and nationalism in the cause of class identity. The discovery that change was a feature of the past, and so part of the natural order, admirably suited a 19th-century view of the world. In this sense, the Palaeolithic past was not so much discovered but invented to meet the requirements of this same class (Gamble 1986, 2021).

The earliest mention of Palaeolithic artefacts discovered in Greece was by French archaeologist François Lenormant in Revue Archéologique in 1867, referring to a bifacial tool found somewhere in the Megalopolis Basin in the central Peloponnese (Lenormant 1867). The exact location where this artefact was found, along with the rest of the material mentioned in his publication was never confirmed, but the basin is likely to be the origin. Other early mentions of Palaeolithic artefacts from Greece were by the French archaeologist Henri Breuil in 1923 and the German historian and anthropologist Hugo Obermaier in 1926, with the latter attempting to place the sparse local evidence within the wider Eastern Mediterranean context (see Kourtesi-Philippakis 1996, and references therein). At the same time, the important palaeontological site of Pikermi in eastern Attica had been known about since 1836, after its discovery by the Scottish historian George Finlay (Runnels 2003, 2008; Karadimas 2013), attracting local and international scientific interest (Karkanis 2012: 601-602). At the turn of the century, significant palaeontological discoveries were also made in the Mytelinii Basin on the island of Samos (Koufos 2009). The first systematic Palaeolithic excavations were carried out during the years immediately before the Second World War, by the Austrian speleologist Adalbert Markovits at Zaimi and Ulbrich caves in southern Greece (Galanidou 2003). Excavations were also carried out at the small cave of Seidi in central Greece by Rudolf Stampfuss in 1941, professor of Prehistoric Archaeology at the University of Dortmund, under the auspices of the German Archaeological Institute at Athens. Despite the importance of these excavations for our understanding of Late Pleistocene human presence in Greece, the discoveries generated little interest amongst local scholars. A few years later, professor of Archaeology at the University of Athens, Spyridon Marinatos, published a short article in which he cast doubt 
on the true character and origin of the discoveries by Markovits and Stampfuss (Marinatos 1945). In 1956, Seidi was briefly reinvestigated by Elisabeth Schmid, professor of palaeontology and zooarchaeology at the University of Basel in Switzerland. The results of her work were presented in 1961 at the 4th International Meeting of the Speleological Society, where they received a warmer response (Varvarousis 2013: 148).

But the real growth in Palaeolithic archaeology in Greece occurred during the period between the late 1950s and the 1980s when several systematic research programmes including excavations and regional surface surveys were initiated by German, British, French and American scholars (Kourtessi-Philippakis 1996:5-19; Elefanti \& Marshall 2015; Vavouranakis \& Kourtessi-Philippakis 2021). Although these were predominantly foreign initiatives, two Greek scholars played a major role in the direction that research was to take. Firstly, the collaboration between the prehistorian Demitrios Theocharis and his German colleague Vladimir Milojčić led to the discovery of a series of Palaeolithic findspots along the banks of the Pineios River in Thessaly (Milojčić et al. 1965). Secondly, the work of the late Avgoustos Sordinas in the Ionian islands in the 1960s led to the discovery and subsequent excavation of several important Palaeolithic and Mesolithic sites, including Grava Cave and open-air Sidari (Sordinas 1969). Beginning in the 1990s, several multidisciplinary projects were initiated, with the collaboration of Greek and foreign scholars. The result is that far from being a terra incognita, the Palaeolithic of Greece is now well established with increasing numbers of sites, a growing body of dates and specialist studies that connect the local evidence with the international discourse (Galanidou 2014; Elefanti \& Marshall 2015; Tourloukis \& Harvati 2017).

\section{Presentation of the Palaeolithic in Greek museums}

But despite all of this scientific progress and international recognition, it would be fair to say that the public understanding and perception of the Greek Palaeolithic remains patchy, a point which is underlined by the small number of museums in which material from the period is presented, as well as by the variability in museological approaches. In the following section, some similarities and differences amongst the various institutions and their collections are presented, providing an overview of the attitudes towards Palaeolithic archaeology in Greece.

Currently, the Palaeolithic and Mesolithic are presented in only a small number of regional archaeological museums, including those in Ioannina, Igoumenitsa, Arta and Corfu in northwestern Greece, and in Thessaloniki and the Anthropological Museum in Halkidiki in northern Greece. There is also the Diachronic Museum of Larisa, the Athanasakeio Museum in Volos and the Theopetra Cave Documentation and Education Centre, all three in central Greece. In contrast to these regional museums, the Palaeolithic and Mesolithic are completely absent from the largest, most prestigious and oldest museum in Greece, the National Archaeological Museum in Athens. The permanent prehistoric collection hosts some of the most characteristic and exquisite artefacts from the Neolithic, Cycladic and Mycenaean periods from throughout the country (Kaltsas 2007). With a single artefact on display, the museum in Arta is not included in the present discussion. The first point that needs to be highlighted is that in most cases the inclusion of the Palaeolithic and Mesolithic within the permanent exhibitions of these regional museums 
is a quite recent phenomenon, in most cases from the early 2000s onwards. It is associated either with the opening of new museums, as is the case of Igoumenitsa, Larisa, and Theopetra, or with the reorganisation of existing ones, for example, Thessaloniki, Ioannina, Nafplio and Corfu. In all cases, these museums are located in areas where Palaeolithic research has progressed significantly during the last two decades.

The Archaeological Museum of Thasos was built in 1934 and has a single display case detailing the ochre mines on the island during the Late Upper Palaeolithic, with descriptions and material including stone and bone tools. Below the panel is a window in which the ochre rich sediment can be seen.

In the Diachronic Museum of Larissa, inaugurated around six years ago, the focus is also on the stone tools and bones from the fluvial deposits along the Peneios River. The display consists of a single case and brief descriptions with stone tools and the bones of large mammals presented together.

The Athanasakeio Archaeological Museum of Volos was built in 1909, with the displays detailing life during the Neolithic widely praised for their pioneering and novel approach, not only during the mid-1970s when they were created, but still today (Malakasioti 1990; Chourmouziadi 2006). The early prehistory displays consist of chipped stone and other artefacts and an information board. The artefacts are from a private collection donated to the museum by A. Bastis and much of the material appears to have been collected along the banks of the upper reaches of the Peneios River. In addition to the vertically mounted display cases, there is a panel describing in some detail, Lower, Middle and Upper Palaeolithic chipped stone working, along with a schematic chronology of the period.

The Archaeological Museum of Thessaloniki was opened in the early 1960s and has a range of displays ranging from the prehistoric to late antiquity. The early prehistory display is housed in three cases, two of which contain skull casts while the third contains chipped stone artefacts collected from the wider area. The first of the two cases contain casts of late Miocene primate skulls from Greece (Ouranopithecus macedoniensis), while in the second is a cast of the Middle Pleistocene hominin cranium from Petralona Cave (Harvati 2009). This juxtapositioning of palaeontological and paleoanthropological finds may be confusing for visitors as it suggests a connection between the two, despite the significant chronological gap that exists. In addition to the displays, there is a brief entry for the Palaeolithic in the online guide for the museum (Grammenos 2004) produced by the John S. Latsis Foundation, as part of their series for selected Greek museums.

The Igoumenitsa Archaeological Museum is relatively new, having been inaugurated in 2009. The displays include chipped stone artefacts from Palaeolithic and Mesolithic sites excavated in Thesprotia during the 1960s, along with more recent material recovered during the construction of the new Egnatia motorway linking Igoumenitsa with Thessaloniki. Arranged within five thematic galleries along with extensive use of multimedia, the museum has become a popular attraction and centre for learning. The early prehistory displays include two cases, the first with Middle Palaeolithic chipped stone tools and the second with Upper Palaeolithic, along with an information panel summarising aspects of the hunter-gatherer way of life, the natural environment and chronology. In addition, there is a brief entry in the guidebook, along with representative images of stone tools (Kanta-Kitsou et al. 2008). 
Another museum with a new display area is the Archaeological Museum of Corfu in Corfu Town. After a complete renovation between 2012 and 2016, the museum now hosts displays of Palaeolithic, Mesolithic and Neolithic chipped and ground stone tools, along with early pottery and some animal bones as well as Bronze Age material, housed within a gallery dedicated to the late Avgoustos Sordinas. The artefacts include chipped stone from Grava and Sidari, which were excavated by Sordinas during the mid-1960s, along with archaeological and palaeontological material from the Korissia Lagoon, as well as from the more recent investigations on the Diapontian islets.

Another facility with new displays is the Archaeological Museum of Nafplio. The permanent exhibition covers two floors of the early 18th-century building in which the museum is housed and is organised chronologically as well as thematically, spanning all the major cultural phases and sites represented in the Argolid. The Palaeolithic is represented by a single panel depicting a schematic of the Franchthi stratigraphic sequence and the relevant cultural phases (Fig. 1), with the background formed by a large photograph of the path along the beach towards the cave, along with small panels with representative chipped stone and other artefacts. Also, on display but with very little contextual information is part of the 30,000-year-old hearth complex from Klissoura Cave (Karkanas et al. 2004), which was lifted intact during the excavations at the site in the Klissoura Gorge just to the north of Nafplio. In addition to the displays in Nafplio, restoration work at Franchthi Cave itself took place between 2011-2013. This included the construction of a new path from the beach up to the entrance of the cave, along with a visitor walkway within (Fig. 2). The work also included the stabilisation of boulders at the entrance, backfilling of the eroded faces of some of the excavation trenches and the preservation for display purposes of a representative section of the stratigraphic sequence. Information boards were also added, with details on the chronology, palaeoenvironmental evidence and history of research in selected areas. Also restored within the cave is a traditional animal pen that was used for decades by a local shepherd. All of this work was brought together in a bilingual information leaflet, which was also produced in Braille, a first for a site in Greece and a commission for the Centre for Education and Rehabilitation for the Blind, providing them with a small profit. Unfortunately, access for visitors with mobility issues is not possible, given the rugged nature of the local topography and the distance from the closest car park. Thanks to its location and stunning natural surroundings, the site has proved to be a popular destination for visitors.

The Archaeological Museum of Ioannina was designed by the distinguished Greek architect Aris Konstantinidis and built in the early 1960s. After an extensive renovation between 2002 and 2008, the permanent exhibitions were organised around seven thematic topics, ranging from the early human occupation of Epirus until the Late Roman period. The first gallery on entering the museum is devoted to the Palaeolithic and Mesolithic, with information boards and material from the nearby cave and open-air sites on display. 


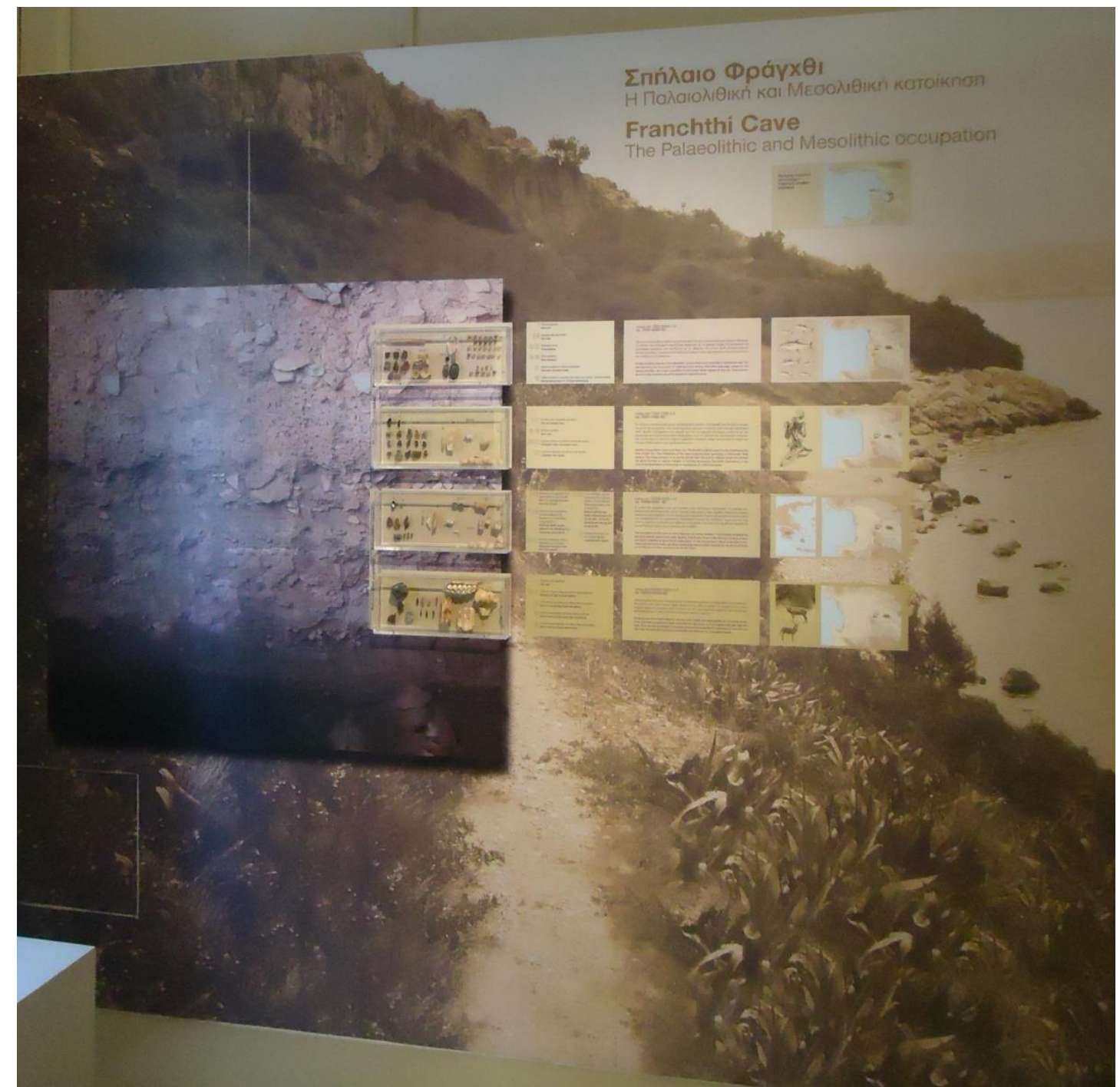

Figure 1. Panel at the Archaeological Museum of Nafplio depicting the succession of Palaeolithic and Mesolithic layers at Franchthi Cave OParaskevi Elefanti. 


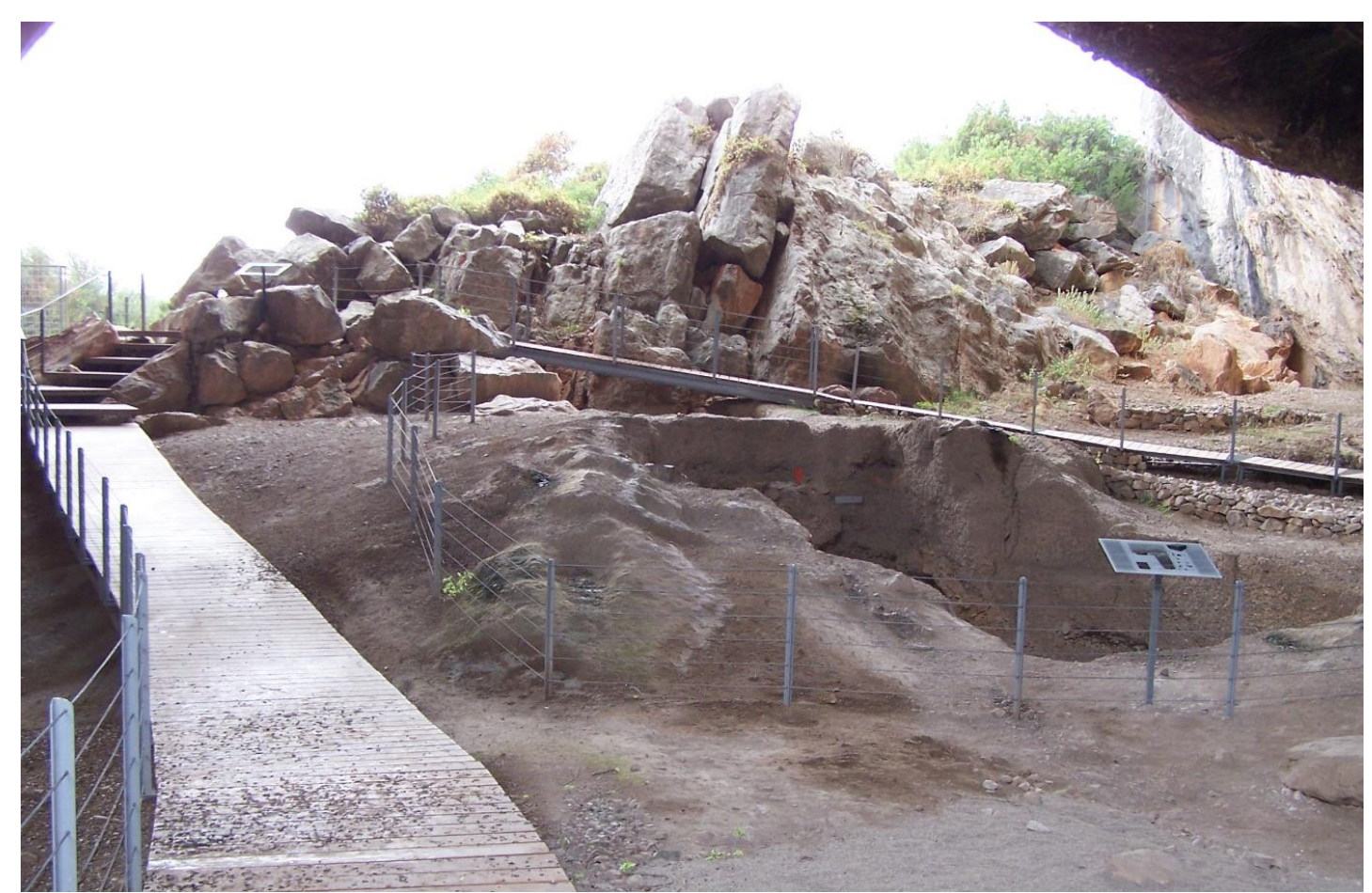

Figure 2. The interior of Franchthi Cave after the completion of the valorisation work CParaskevi Elefanti.

The display cases are large and allow visitors to view the objects from multiple angles, while panels provide detailed information on specialist topics including technology, subsistence, symbolism and cognition (Fig. 3). There are also multimedia displays in which the natural environment and stone tool manufacture is described. The Lower Palaeolithic handaxe from the open-air site of Kokkinopilos features prominently at the entrance. Another engaging feature of the gallery is a banner that extends along the wall, with snapshots of the excavations at four key Palaeolithic and Mesolithic sites in Epirus, Kastritsa Cave and the rock shelters of Asprochaliko, Klithi and Boila, all of which were excavated during the four decades beginning in the 1960s. On the occasion of the reopening of the museum in 2008, a thematic limited-edition book covering the history of Epirus from the earliest human presence up until late antiquity was produced. The Palaeolithic and Mesolithic included two contributions in which hunter-gatherer subsistence, culture and technology were presented (Adam 2008; Kotjabopoulou 2008). 


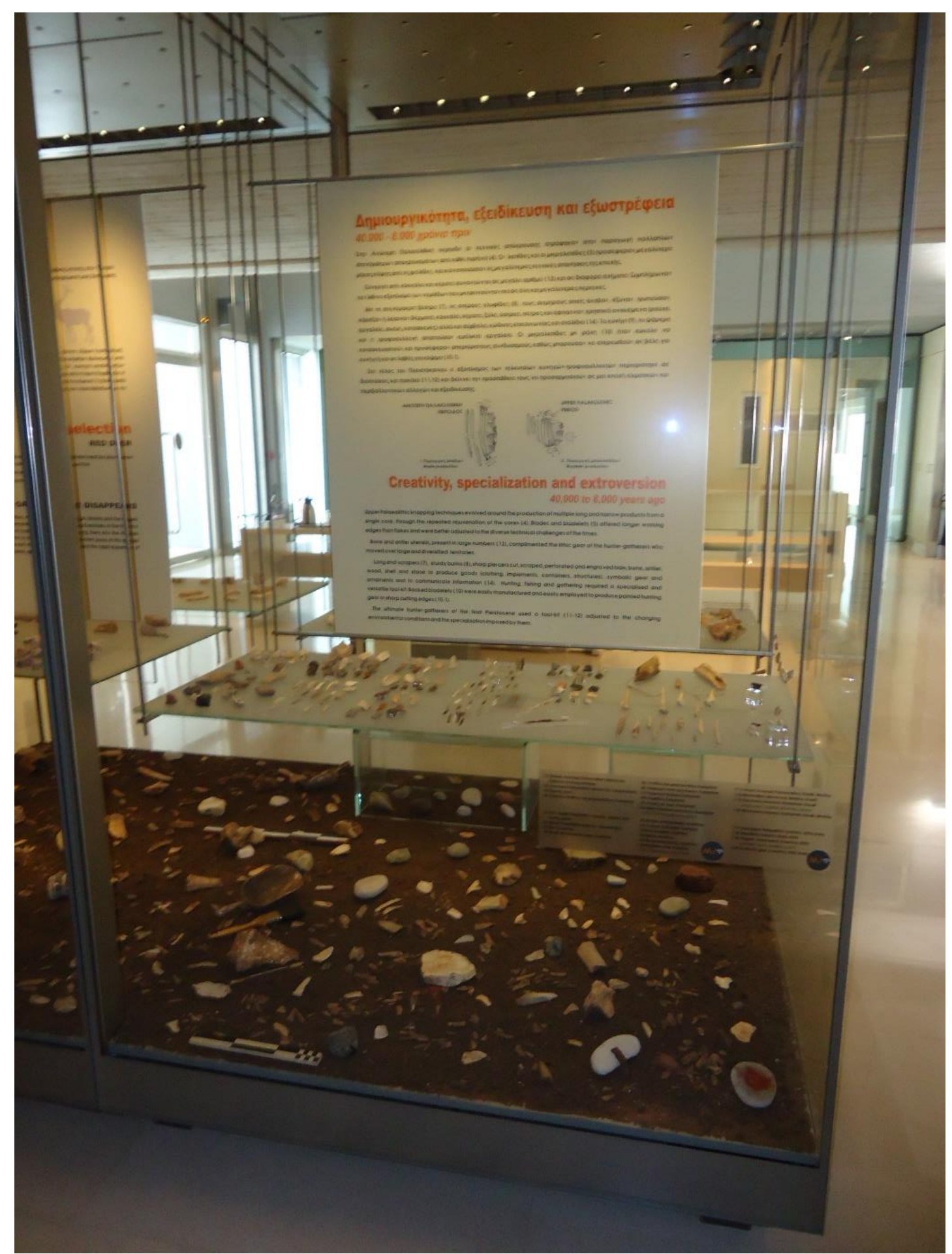

Figure 3. Display case at the Archaeological Museum of Ioannina with Middle Palaeolithic artefacts CParaskevi Elefanti.

The Theopetra Cave Documentation and Education Centre in the village of Theopetra represents a new departure for museums in Greece, in that it exclusively promotes the results from the excavations at the nearby site of Theopetra Cave. Inaugurated in 2015, the displays cover the occupation of the cave from the Middle Palaeolithic until the Neolithic, with the centre developed under the auspices of the Ephorate of Palaeoanthropology and Speleology (Kyparissi-Apostolika 2016). It functions as a hub for information and teaching with extensive educational programmes, featuring displays of 
material from the site (Fig. 4), along with multimedia facilities. Also on display are blocks of sediment lifted intact, including a Mesolithic burial, a series of footprints and a hearth. Along with information boards and interactive activities, the displays allow visitors to familiarise themselves with the history of the cave, the types of people who occupied it and the surrounding natural environment. They also provide a taste of the practical aspects of archaeological investigation, the trench system, the concept of stratigraphy and the kinds of information that can be deduced from the objects recovered.

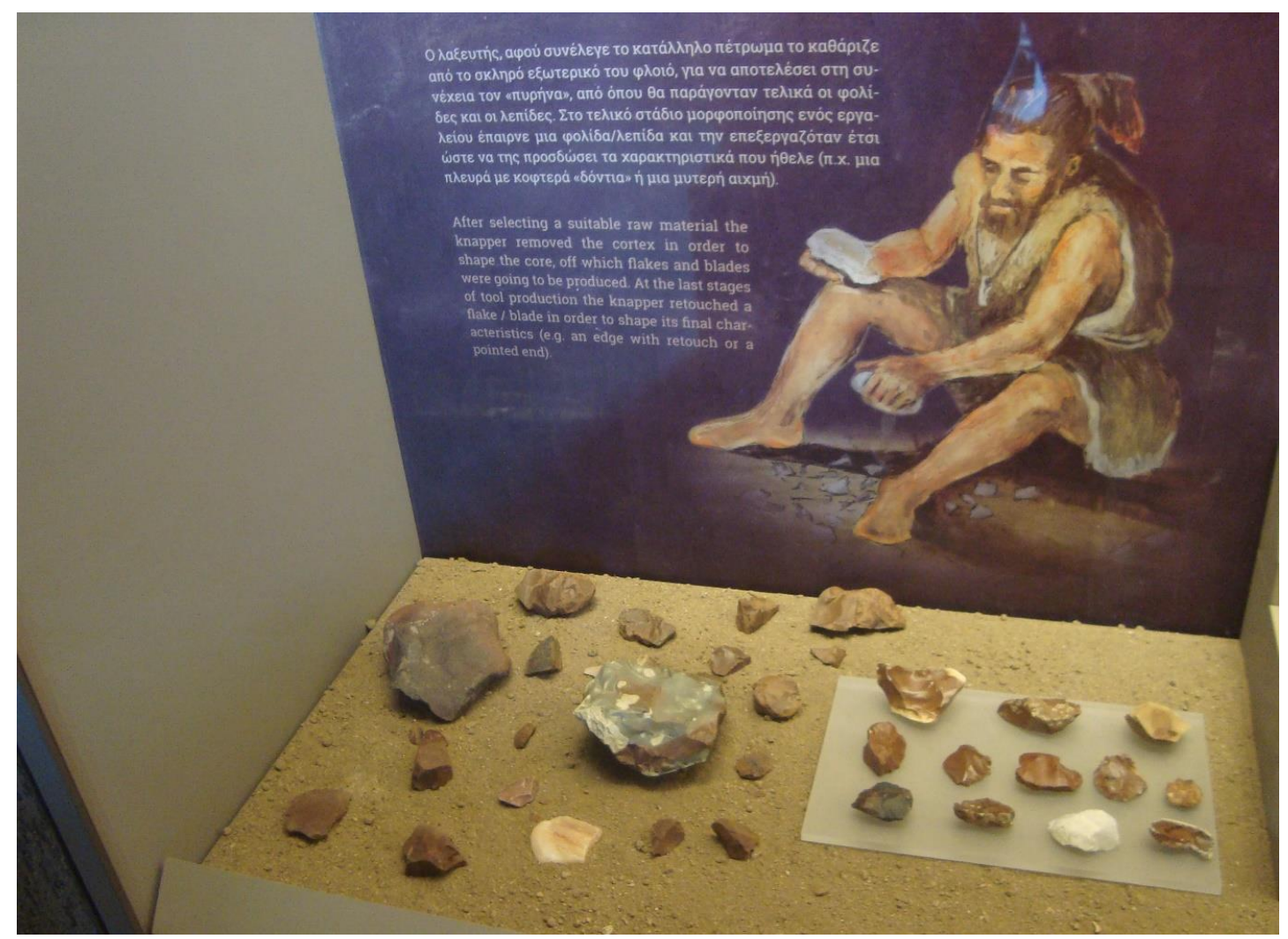

Figure 4. Display case at the Theopetra centre containing Middle Palaeolithic artefacts CP. Kangaras.

In addition to the centre, the cave itself has been well-integrated within the visitor experience. Walkways have been constructed around the outer walls, providing spectacular views of the excavation trenches and the stratigraphy, allowing visitors a firsthand experience of what life must have been like for the occupants of the cave, as well as the work involved in excavating it (Fig. 5). In addition, several prominent features have been left unexcavated and on display, including a series of hearths. Despite its location well above the plain of Thessaly, the cave has nearby parking facilities and is serviced by a lift, allowing access for visitors with restricted mobility, while the centre in the village is also accessible via a ramp. Theopetra is well integrated within the regional tourist network of Thessaly, forming part of the Integrated Territorial Investment along the culturaltourism route included in the approved Regional Operational Programme of Thessaly 2014-2020. The route includes important monuments in Thessaly and extends from Trikala and Meteora in the west to Magnesia in the east.

Petralona Cave and the adjacent museum are both currently closed for restoration, with the work being undertaken by the Ephorate of Palaeoanthropology-Speleology. 
Previously, the cave and the museum were operated under the aegis of the Anthropological Association of Greece. The displays included a cast of the Petralona cranium and life-size representations of early humans carrying out daily tasks, along with bones and various static models of prehistoric and historic animals. Also on display were chipped stone tools from the Palaeolithic and later periods, along with information on early human origins by the founder of the museum and the Anthropological Association of Greece, Aris Poulianos. Petralona Cave and the museum was a popular attraction for visitors and school groups, although it would be fair to say that the displays and the interpretations attributed to the finds have proved controversial. The work has only just begun on the restoration and it remains to be seen how the cave and museum will be presented in the future. Like Franchthi and Theopetra, the cave of Petralona and the adjacent museum will function together to enhance the visitor experience, with the early prehistoric occupation of the area being at the heart of the displays.

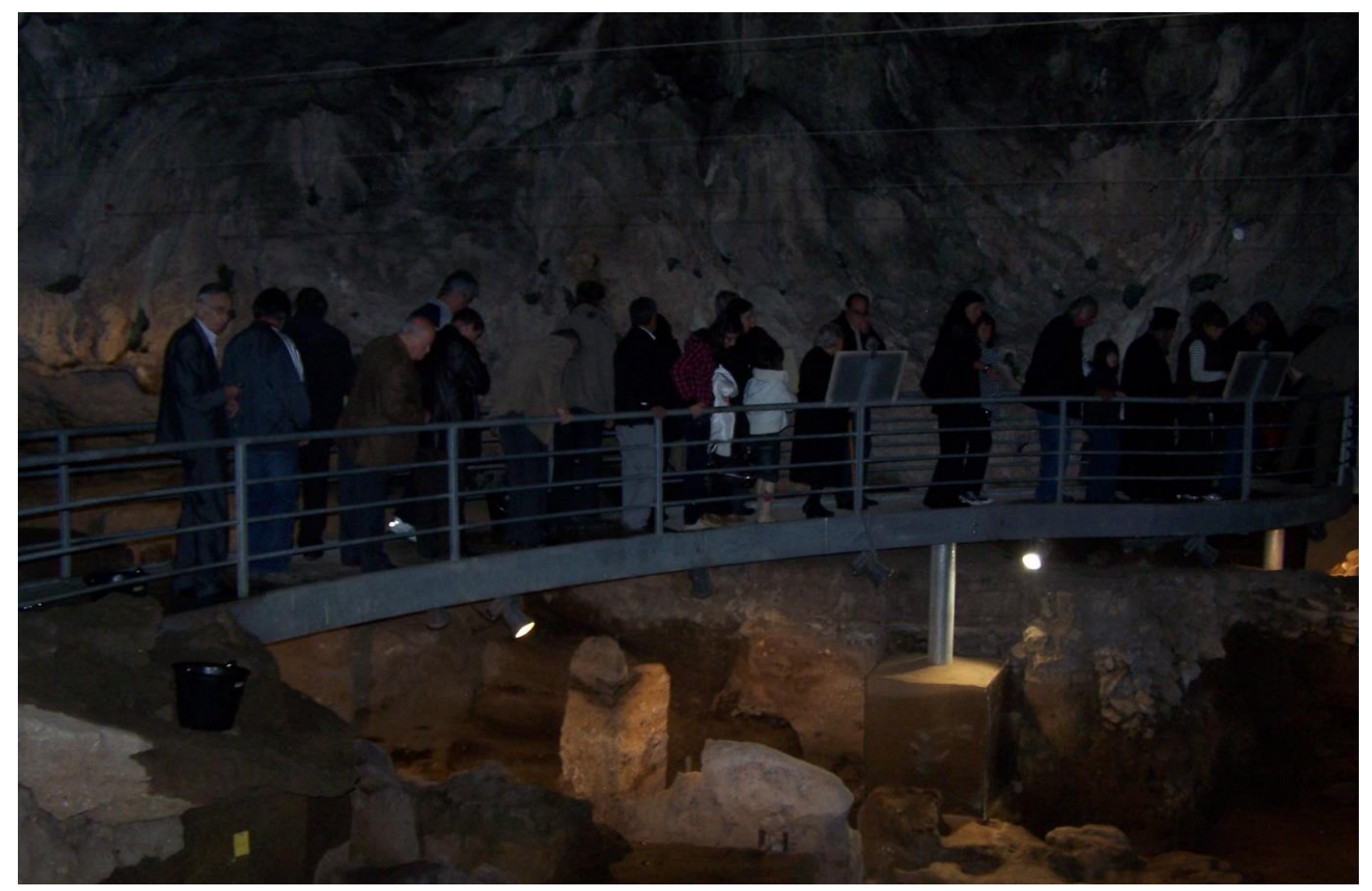

Figure 5. Official opening of Theopetra Cave to the public in 2010 CParaskevi Elefanti.

\section{Discussion}

Museums say more about their own time and culture than they do about the past which they are supposed to represent (Gazi 1994: 50-51). The lack of emphasis on early prehistory in museums in Greece is a reflection of minimal public awareness and the perception that later periods played a much more important role in shaping the nation. With a century of research in human origins in Greece, the evidence for the important role played by the region has accumulated to the extent that it now features within international discourse. Despite this, understanding of and interest in the period remains minimal, resulting in limited public and state engagement.

One of the reasons for this may be due to the nature of much of the archaeological record in the region, with material from surface scatters and fluvial deposits lacking any 
stratigraphy, both chipped stone and animal bones. Although useful in terms of demonstrating presence, such remains are less able to capture the public imagination (Carter 2017). The education system has not helped either, with a notable decline since the 1990s in the time allocated for teaching early prehistory in the primary school history curriculum (Kasvikis et al. 2012). It is not covered at all during secondary education, reinforcing ethnocentric identities and rejecting any notion of 'otherness' and diversity (Hamilakis 2003).

Limited historical knowledge coincides with an emphasis on the use of stereotypes and parochial views about the primitiveness of early humans and their hunter-gatherer way of life. The latter, reproduced worldwide in popular culture and as metaphors for old fashion ideas, brutal behaviour and limited cognitive ability, are important factors when considering the lack of public engagement (Moser 1998). Most museums in Greece do not help in countering such attitudes, as in the majority of cases early prehistory is only very briefly covered, often merely providing a convenient starting point for the rest of the displays.

In most museums, the Palaeolithic and Mesolithic is predominantly represented by the most abundant and generally best-preserved evidence, chipped stone tools. These are arranged within display cabinets with little contextual information apart from a name defined by their assumed function. Their true purpose as problem-solving strategy (Binford 1977) is lost, along with the fact that both making and using them involved corporeal experience and a reflection of individual skills, identity and social relationships (Dobres 2000; Elefanti \& Panagopoulou 2016). Individual objects lacking in context or narrative are unable to reveal the complexities of the lives of those who made them and as a result, it is difficult for visitors to understand or engage with them.

Another factor that has played an important role in shaping the public perception of early prehistory is related to the link between archaeology and the national agenda. The political conditions that followed the foundation of the independent Greek state in 1830 included a systematic effort to restore the nation to a condition considered worthy of its perceived ancient precedent. For Greeks, the connection with the Classical past was deeply rooted and this was actively exploited by the Greek state to foster and consolidate its distinctive national identity, while many other nations in Europe and beyond also drew linkages between their own histories and that of ancient Greece and Rome. In the newly founded Greek state, monuments and material culture provided readily exploitable national symbols. Archaeology became the national discipline par excellence and was invested with considerable ideological and political capital (Gazi 2014: 365). Greeks attributed to this past not only the restoration of their national pride, but more importantly their status as an independent state, given Europe's identification with the ancient Greeks and their perceived differences from the Ottomans (Mazower 2008: 33).

The claim by the Austrian historian Jakob Philipp Fallmerayer in 1830 that today's Greeks bear no biological connection with the ancient Greeks, having been heavily mixed with the Slavs from the sixth century onwards, had a serious and long-lasting effect on Greek scholars (Skopetea 1988). They redoubled their efforts to show that even if the biological link between modern Greeks and their ancient predecessors was broken, their cultural connection could be easily proven. The entire body of the humanities, history, archaeology and early folk studies (Voutsaki 2003; Gazi 2014), as well as biology, with its main 
proponent Klon Stefanos, one of the founders in 1886 and first director of the Anthropological Museum of the University of Athens (Karamanolakis \& KourtesiPhilippakis 2017), set out to prove Fallmerayer wrong.

In history, this notion of cultural continuity is best represented by Konstantinos Papareghopoulos, who published his seminal work in 1925, History of the Greek Nation, From Antiquity to Modern Times. Here he presented his tripartite division of the main periods in the history of the nation, with specific emphasis on its strong Hellenic connection, including ancient, medieval and modern Hellenism (Karamanolakis 2018). In a similar vein and sponsored by the Archaeological Society at Athens, the archaeologist Christos Tsountas undertook excavations at Mycenae in 1886, following those of Heinrich Schliemann a decade earlier. From this point onwards, the Mycenaean and Minoan civilizations, which had also been identified during excavations on Crete, were endorsed as European and were acknowledged as the earliest signs of a continuous and unbroken Greek civilisation, pushing the evolutionary scheme of Papareghopoulos even further back (Karamanolakis 2018: 673, Voutsaki 2003, 2017 Polychronakou-Sgouritsa 2019: 276-277). The views of Tsountas regarding the linear and unbroken connection between ancient and modern Greece had a significant impact on the organisation of the National Archaeological Museum in Athens, which, to fill the ideological and chronological gap between prehistoric and historical times, placed particular emphasis on antiquities from the Mycenaean culture (Nikolentzos 2020: 352).

Earlier evidence such as that from the Neolithic was seen as unimportant (Runnels 2003, 2008) and when present, was merely viewed as a prelude to the Classical period (Kotsakis 1991; 2008, Voutsaki 2003: 250-251). Humble and perishable Palaeolithic cultural remains were and are still excluded from the displays, where the aim was to bolster national pride and identity, rather than to provide a balanced picture of the past. This has resulted in a hesitancy to adopt more critical approaches to the past, which would allow for continuous reinterpretation and the placing of greater emphasis on neglected periods (Gazi 2014: 391).

The Palaeolithic, a period with no state borders, established nations, national symbols or written history and with mobile communities moving across vast territories, is unable to speak directly the language of nationalism, at least in the form that the latter has been perceived in the Greek case. It was slightly different in Italy during the interwar period when Italian prehistorians under the influence of Mussolini's nationalistic propaganda and the German search of the Aryan tribe, began to speculate on the existence of a Mediterranean race, claiming a Neanderthal skull found in Guattari Cave in 1939 represented the first Italian (McFeaters 2007). Similar important palaeoanthropological discoveries in Greece, such as the archaic human skull from Apidima Cave in the southwestern Peloponnese, the possible evidence for early stone tools on Crete and their implication of seafaring (Strasser et al. 2010), and the footprint evidence for early primates in Crete around six million years ago (Kirscher et al. 2021), have all made recent headlines. The Petralona skull has also added to the debate regarding its morphology and antiquity, with recent studies pointing to it being ancestral to both Neanderthals and modern humans (Harvati 2009, and references therein). Controversially, the skull has been used to argue for Greece as a cradle for humanity, with the remains attributed aspects of 
behavioural modernity, including complex social life, division of labour and elaborate cloth making abilities, amongst others (Poulianos 1991-1997).

The way in which early prehistory is presented in Greek museums strongly reflects the use made of the more recent Classical past in the establishing and reinforcing of the links between the glories of ancient and modern Greece. This has been a useful and successful narrative and is still today exploited in the way that the country is presented on the global stage, not to mention the importance of cultural tourism to the exchequer. In the case of the small number of museums and sites mentioned above in which the Palaeolithic is presented in informed and engaging ways, it is still largely down to the commitment and energy of specific individual staff members working in these museums and local ephorates. The museums in Ioannina and Theopetra are good examples of the role played by such individuals. Following the relatively long history of Palaeolithic and Mesolithic research in Greece which has enriched and altered to some extent its perception, the conditions are now ripe for an exhibition to be organised highlighting the contribution of Greece as a crossroads during early prehistory.

\section{Acknowledgments}

First of all, I would like to thank the editors of the volume for their patience and guidance, along with the two anonymous reviewers for their constructive and helpful comments on the first draft. I would also like to thank Nina Kyparissi-Apostolika, Eleni Kotjabopoulou, Georgia Pliakou, Orestis Apostolikas, and Panagiotis Kangaras for their advice on the museums included.

\section{References}

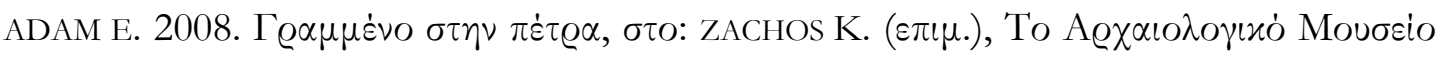

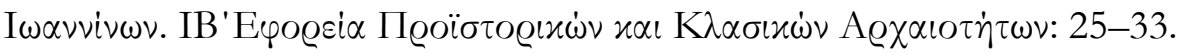

BINFORD L. 1977. Forty-seven trips: A case study in the character of archaeological formation processes, in: WrighT R. (ed.), Stone Tools as Cultural Markers: Change, Evolution and Complexity. Canberra: Australian Institute of Aboriginal studies: 24-36.

CARTER T. 2017. Nothing to see here! The challenges of public archaeology at Palaeolithic Stélida, Naxos. Journal of Eastern Mediterranean Archaeology and Heritage Studies, 5. 3-4: 311333.

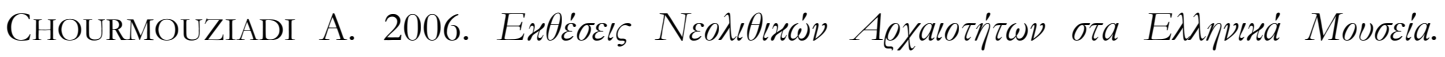

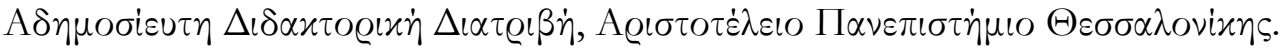

DiAs-ANDREU M. 1995. Archaeology and nationalism in Spain, in: KOHL P.L. \& FAWCETT C. (eds.), Nationalism, Politics and the Practice of Archaeology. Cambridge University Press: 39-56.

Dobres A.M. 2000. Technology and Social Agency. Oxford: Blackwell.

Elefanti P. \& MARShall G. 2015. Late Pleistocene hominin adaptations in Greece, in: Coward F. Hosfield R., Pop M. \& Wenban-Smith F. (eds.), Settlement, Society and Cognition in Human Evolution. Landscapes in Mind. Cambridge: Cambridge University Press, 189-213. 
Elefanti P. \& Panagopoulou E. 2016. Lithics and identity at the Middle Palaeolithic site of Lakonis I, southern Peloponnese, Greece, in: MinA M., TRIANTAPHYLlOU S. \& Papadatos Y. (eds.), An Archaeology of Prehistoric Bodies and Embodied Identities in the Eastern Mediterranean. Oxford \& Philadelphia, Oxbow Books: 113-119.

Elefanti P. \& Marshall G. 2018. Mobility during the Upper Palaeolithic in Greece: Some suggestions for the Argolid Peninsula'. EX NOVO Journal of Archaeology 3: 7-22.

GALANIDOU N. 2003. Reassessing the Greek Mesolithic: The pertinence of the Markovits collections, in: Galanidou N. \& PERLÈS C. (eds.), The Greek Mesolithic. Problems and Perspectives. London: BSA studies 10: 99-112.

GALANIDOU N. 2014. Advances in the Palaeolithic and Mesolithic archaeology of Greece for the new millennium. Pharos 20(1): 1-40.

GALANIDOU N. 2020. Re-inventing public archaeology in Greece, in: Christophilopoulou A. (ed.), Material Culture in Public Archaeology. Re-investing Archaeology Within Museum Collections. United Kingdom and United States: Oxbow books, 77-93.

Gamble C. 1986. The Palaeolithic Settlement of Europe. Cambridge: Cambridge University Press.

Gamble C. \& KRUSzynski R. 2009. John Evans, Joseph Prestwich and the stone that shattered the time barrier. Antiquity 83: 461-475.

Gamble C. 2021. Making Deep History: Zeal, Perseverance and the Time Revolution of 1859. Oxford: Oxford University Press.

GAZI A. 1994. Archaeological museums and displays in Greece: 1829-1909. A first approach. Museological Review 1(1): 50-69.

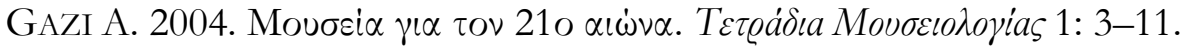

GAZI A. 2014. National Museums in Greece: History, ideology, narratives. Building national museums in Europe 1750-2010. Conference proceedings from EuNaMus, European National Museums: Identity Politics, the Uses of the Past and the European Citizen, Bologna 28-30 April 2011. Aronsson P. \& Elgenius G. (eds.), EuNaMus Report No 1. Published by Linköping University: 363-399.

Gero J.M. \& CONKEY W. 1991. Engendering Archaeology. Women and Prehistory. Oxford: Basil Blackwell.

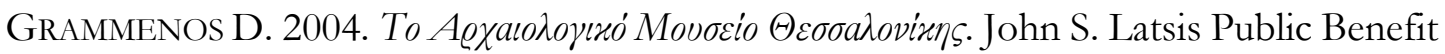
Foundation. https://www.latsis-foundation.org/eng/e-library.

Hitchcock L. \& Nikolaidou M. 2013. Gender in Greek and Aegean Prehistory, in: Bolger D. (ed.), A companion to Gender Prehistory. John Wiley \& Sons: 502-525.

HAMILAKIS Y. 2003. 'Learn history!' Antiquity, national narrative, and history in Greek educational textbooks, in: Brown K.S. \& HamiLakis Y. (eds.), The Usable Past. Greek Metahistories. Lexington Books: 39-67.

HAMILAKIS Y. 2011. Museums of oblivion. Antiquity 85: 253-266.

HAMILAKIS Y. \& THEOU E. 2013. Enacted multi-temporality: The archaeological site as a shared, performative space. In A. GONZALEZ-RUIBAL (ed.), Reclaiming Archaeology: Beyond the Tropes of Modernity. London: Routledge. Pp. 181-194

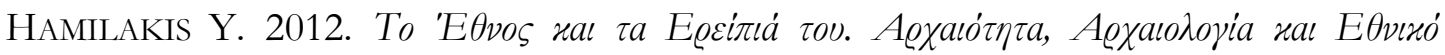

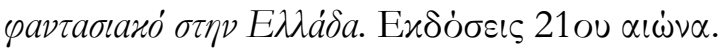


Harvati K. 2009. Petralona: Link Between Africa and Europe? in: SCHePartz L., Bourbou C. \& Fox S. (eds.), New Directions in the Skeletal Biology of Greece. Occasional Wiener Laboratory Series. Athens, ASCSA: 31-49.

HodDer I. 2002. Ethics and archaeology: The attempt at Çatalhöyük. Near Eastern Archaeology 65(3): 174-181.

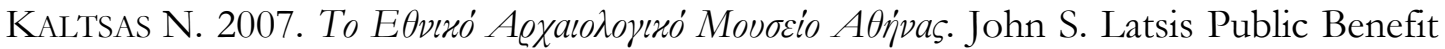
Foundation. https://www.latsis-foundation.org/eng/e-library.

Kanta-kitsou A., Palli O. \& Amagnostou I. 2008. Igoumenitsa Archaeological Museum. Ministry of Culture, 32nd Ephorate of Prehistoric and Classical Antiquities of Thesprotia.

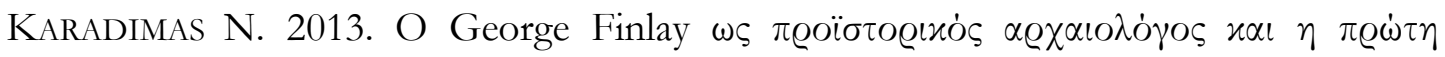

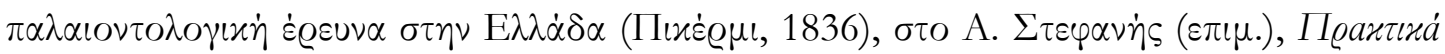

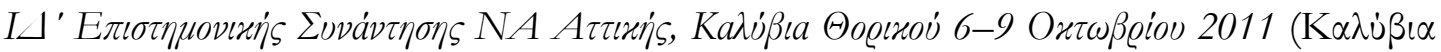

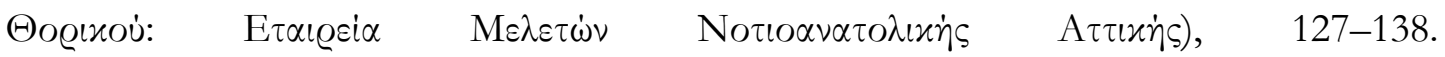
http://www.aegeussociety.org/images/uploads/digital-articles/Karadimas-2013Finlay.pdf

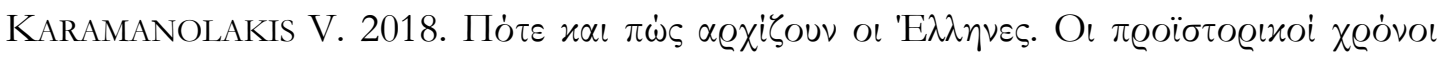

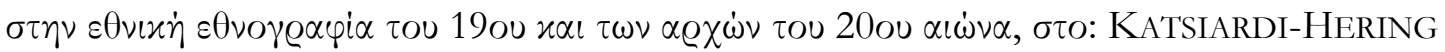

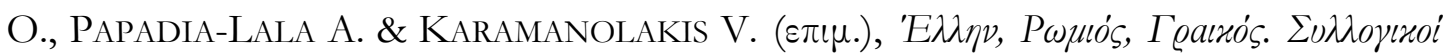

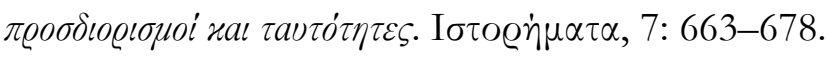

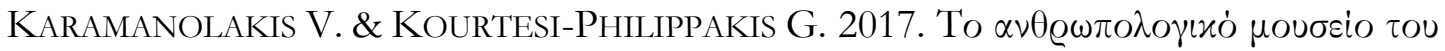

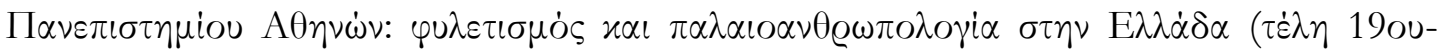

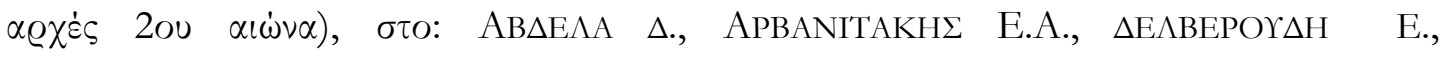

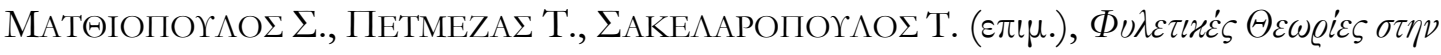

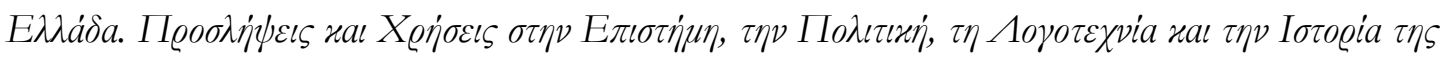

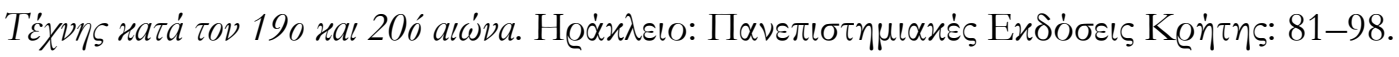

KARKANAS T., KOUMOUZELIS M., KOZLOWSKI J.K., SITLIVY V., 3 K. SOBCZYK K., BERNA F., \& WEINER S. 2004. The earliest evidence for clay hearths: Aurignacian features in Klisoura Cave 1, southern Greece. Antiquity 78 (301):513-525.

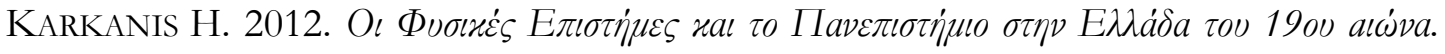

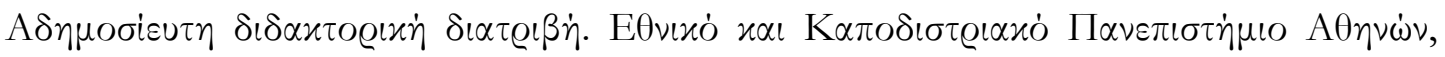

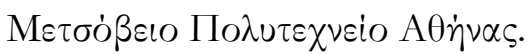

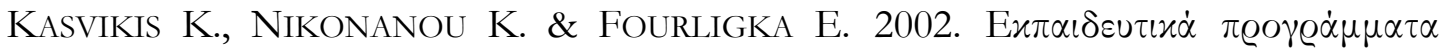

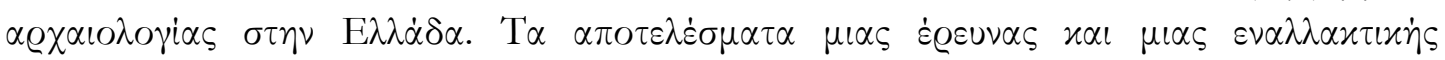

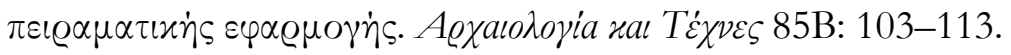

KASVIKIS K., NiKONANOU N. \& KOTSAKIS K. 2007. Developing educational programmes for prehistoric sites: The Greek case study-Paliambela, Kolindros, in: HODDER I. \& Doughty L. (eds.), Mediterranean Prehistoric Heritage. Training, Education and Management. Cambridge: McDonald Institute Monographs: 105-116.

KASVIKIS K. 2012. Prehistory in Greek primary education 1975-2012. Representations of a mythic and Hellenised past, in: SCHÜCKER N. (ed.), Integrating Archaeology. Science-WishReality. International Conference on the Social Role, Possibilities and Perspectives of Classical Studies. Papers held in Frankfurt a. M. on 12-14 June 2012. Frankfurt: Römisch-Germanische Kommission: 121-126.

Kasvikis K., Theodoroudi E., Tsopela A. \& Kotsakis K. 2011. Making Alternative meanings from the past: Approaches to Cultural Diversity in Greek Museums, in: MARCINIAK 
A., Minta-Tworzowskiej D. \& Pawleta M. (eds.), Wspolczesna oblicza przeszlosci (Contemporary faces of the past). Wydawnictwo Poznańskie, Poznan: 253-266.

Kirscher U., Elatfy H., Gartner A., Dallanave E., Munz Ph., Niedźwiedzki G., Athanasiou A., Fasoulas Ch., Linnemann U., Hofmann M., Bennett M., Ahlberg P.E. \& BÖHME M. 2021. Age Constraints for the Trachilos Footprints from Crete 4, Nature 11:19427.

Kokkinidou D. \& Nikolaidou M. 2000. A Sexist Present, a human-less past: Museum archaeology in Greece, in: Donald M. \& Hurcombe L. (eds.), Gender and Material Culture in Archaeological Perspective. London: Macmillan Press: 33-55.

KotSAKIS K. 1991. The Powerful Past: Theoretical trends in Greek archaeology, in: HodDer I. (ed.), Archaeological Theory in Europe. The Last Three Decades. London, Routledge: 65-90.

KOTSAKIS K. 2008. Paths to modernity: Demitrios R. Theocharis and the post-war Greek prehistory, in: Damaskos D. \& Plantzos D. (eds.), A Singular Antiquity. Archaeology and Hellenic Identity in Twentieth-Century Greece. Athens: Mouseio Benaki: 175-183.

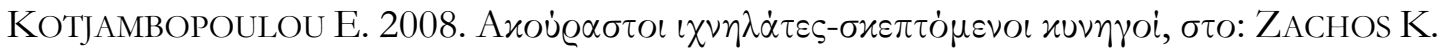

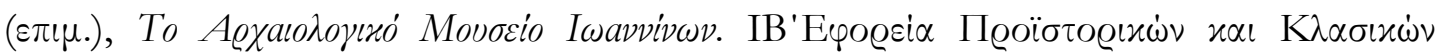

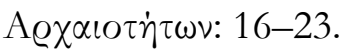

Koufos G. 2009. The Late Miocene Mammal Faunas of the Mytilinii Basin, Samos Island, Greece: New Collection 1. History of the Samos Fossil Mammals. Beitr. Paläont., 31: 1-12.

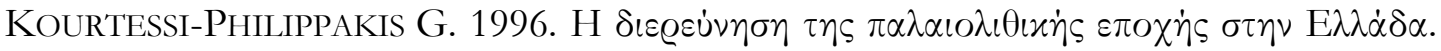
Aexaıodoyia xaı Téxves 59: 6-31.

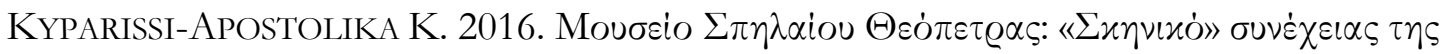

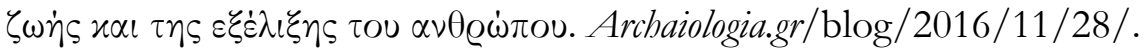

Lenorman F. 1867. L'âge de la pierre en Grèce. Revue Archéologique I: 16-19.

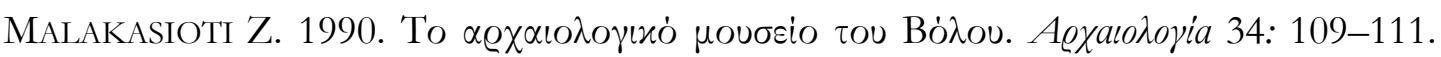

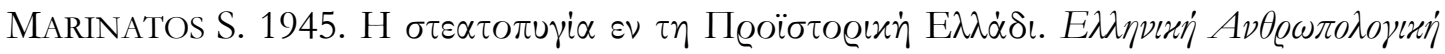

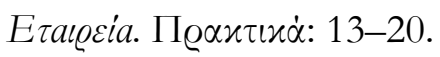

Matsuda A. 2004. The Concept of 'the Public' and the Aims of Public Archaeology. Papers from the Institute of Archaeology 15: 66-76.

MAZOWER M. 2008. Archaeology, nationalism and the land in modern Greece, in: Damaskos D. \& Plantzos D. (eds.), A Singular Antiquity. Archaeology and Hellenic Identity in Twentieth-Century Greece. Athens: Mouseio Benaki: 33-41.

McFeaters A. 2002. The Past is how we present it: Nationalism and archaeology in Italy from unification to WWII. Nebraska Anthropologist 33: 49-62.

McGimsey C.R. 1972. Public Archaeology. New York and London: Seminar Press.

Merriman N. 2004. Public Archaeology. London: Routledge.

Milojcic V., Boessneck J., Jung G. \& Schneider H. 1965. Paläolithikum um Larissa in Thessalien. Bonn, R. Habelt (Beitage zur Ur und Fruhgeschichtlichen Archaologie des Mittelmeer Kulturraumes, t.1.

Moser S. 1998. Ancestral Images. The Iconography of Human Origins. New York: Sutton Publishing.

Mouliou M. 2008. Museum Representations of the Classical past in post war Greece: A critical analysis, in: Damaskos D. \& Plantzos D. (eds.), A Singular Antiquity. Archaeology and Hellenic Identity in Twentieth-Century Greece. Athens: Mouseio Benaki: 83-109. 
Nikolentzos K. 2020. The display of the prehistoric antiquities at the National Archaeological Museum in the late 19th Century: Ideology and formation of national identity, in: Logogianni-GeOrgakarakos M. \& Koutsogiannis TH. (eds.), These are What we Fought for. Antiquities and the Greek War of Independence. Athens: Archaeological Resources Fund: 351-359.

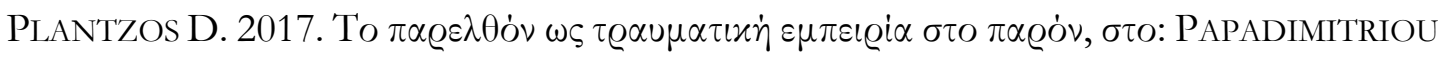

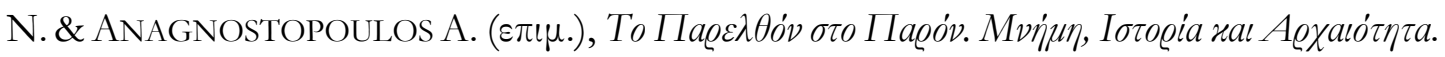

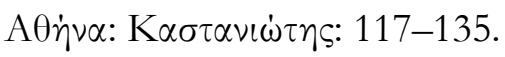

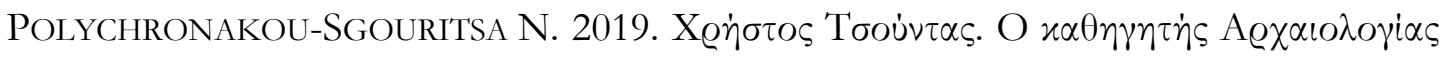

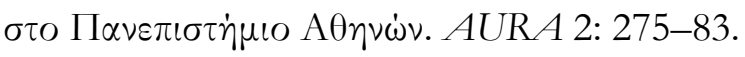

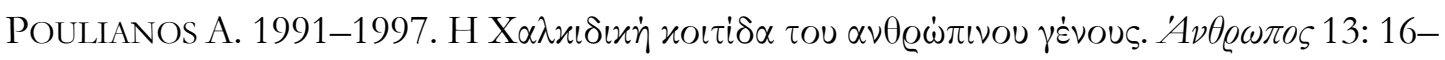
60.

RunNELS C. 2003. The history and future prospects of Paleolithic archaeology in Greece, in: Papadopoulos J. \& Leventhal R. (eds.), Theory and Practise in Mediterranean Archaeology: Old World and New World Perspectives. Los Angeles: 181-193.

RunNELS C. 2008. George Finlay's contributions to the discovery of the Stone Age in Greece. The Annual of the British School at Athens 103: 9-25.

SAKELlariadi A. 2008. Archaeology and museums in the nation building process in Greece, in: Aronsson P. \& Nyblom A. (eds.), Comparing National Museums, Territories, Nation-Building and Change. NaMu IV, Linköping University, Norrköping, Sweden, 18-20 February 2008: 129-142.

SAKellariadi A. 2011. Archaeology for the People? Greek. Archaeology and its Public: An Analysis of the Socio-political and Economic Role of Archaeology in Greece. Unpublished Ph.D. Thesis. UCL Institute of Archaeology.

SCHADLA-HALl T. 1999. Editorial: Public Archaeology. European Journal of Archaeology 2(2): 147-158.

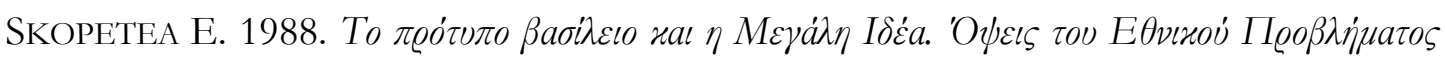

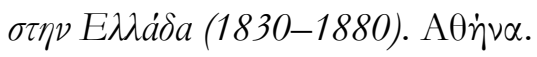

SORDINAS A. 1969. Investigations of the Prehistory of Corfu During 1964-1966. Balkans Studies 10(2): 394-424.

Strasser T.F., Panagopoulou E., Runnels C., Murray C., Thompson N., Karkanas P., McCoy F.W. \& Wegmann K.W. 2010. Stone Age seafaring in the Mediterranean: Evidence from the Plakias Region for Lower Palaeolithic and Mesolithic Habitation of Crete. Hesperia 55: 782-802.

Tourloukis V. \& Harvati K. 2017. The Palaeolithic record of Greece: A synthesis of the evidence and a research Agenda for the future. Quaternary International 466A: 48-65. Trigger B.C. 1989. A History of Archaeological Thought. Cambridge University Press.

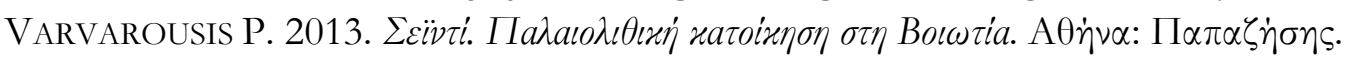
VAvouranakis G. \& Kourtesi-PhilippaKis G. 2021. Antiquity all over the place: Evolutions and revolutions in early prehistoric research in Greece during the 1960s, in: de Beaume S., Guidi A., Abadìa O.M., Tarantini M. (eds.), New Advances in the History of Archaeology. Proceedings of the XVIII UISPP World Congress (4-9 June 2018, Paris, France). Oxford: Archaeopress Archaeology 16:126-137.

VOUTSAKI S. 2003. Archaeology and the construction of the past in nineteenth century Greece in: HOKWERDA H. (ed.), Constructions of Greek Past. Identity and Historical 
Consciousness from Antiquity to the Present. Groningen: Egbert Forsten: 231-255.

VOUTSAKI S. 2017. The hellenisation of Greek prehistory: The work of Christos Tsountas, in: Voutsaki S. \& Cartledge P. (eds.), Ancient Monuments and Modern Identities: Towards a Critical History of Archaeology in 19th and 20th Century Greece. Routledge, London. 